\title{
A Critical Look at Bioproducts Co-cultured Under Solid State Fermentation and Their Challenges and Industrial Applications
}

\author{
Girisa Prabhu ${ }^{1} \cdot$ Divya Bhat $^{1} \cdot$ Ramananda M. Bhat $^{1} \cdot$ Subbalaxmi Selvaraj $^{1}$
}

Received: 22 August 2021 / Accepted: 6 February 2022 / Published online: 22 February 2022

(c) The Author(s) 2022

\begin{abstract}
The production of bioproducts from microorganisms is a common practice in many industries for a long time now. In recent years, studies have proved that co-culturing microorganisms increase the yield of products by synergistically degrading the solid substrate in comparison with individual cultures. The review highlights the benefits of co-culturing microorganisms using solid state fermentation (SSF) to achieve higher productivity. Filamentous fungi of genus Trichoderma, Penicillium, and Aspergillus are extensively studied and used for co-culturing and mixed culturing under SSF. Co-cultured microorganisms are beneficial because of the synergistic expression of metabolic pathways of all the microorganisms. Co-culture enables combined metabolic activity at optimal process conditions for better utilization of substrates. Depending on the nature of the process and microorganism, bioreactors are designed and operated. This review mentions various purification methods that are used to improve the purity of the products obtained. The strengths and weaknesses of various bioreactors and their effect on the microorganisms used are explained in detail. This review also identifies the challenges of co-culturing microorganisms and analyses the diverse set of fields in which SSF finds its applications.
\end{abstract}

\section{Graphical Abstract}

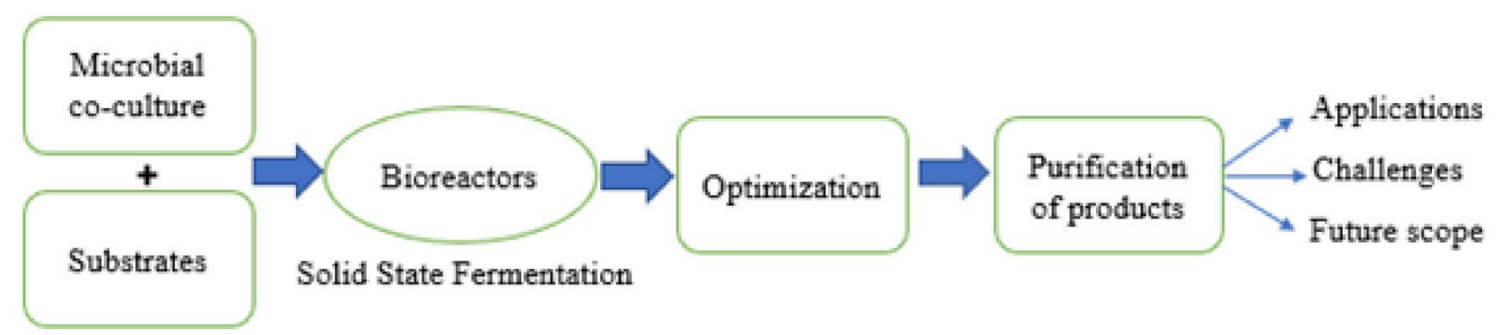

Keywords Co-culture $\cdot$ Microbial bioproducts $\cdot$ Solid state fermentation $\cdot$ Bioreactors $\cdot$ Optimization $\cdot$ Purification . Applications

Girisa Prabhu and Divya Bhat have contributed equally to this work as first authors.

Ramananda M. Bhat

mr.bhat@manipal.edu

Subbalaxmi Selvaraj

subbalaxmi.s@manipal.edu

1 Department of Biotechnology, Manipal Institute of Technology, Manipal Academy of Higher Education (MAHE), Manipal 576104, India

\section{Statement of Novelty}

This review provides updated literature on co-culture studies using Solid State Fermentation. Reports on new substrates and microorganisms with co-culture are elucidated for diverse applications. The paper highlights purification methods and approaches for enhancing the yields of products. Results of optimization studies carried out are also described in a separate section. Under the future scope, the scale-up of co-culture studies with different types of bioreactors that are suitable for solid state fermentation is explained. 


\section{Introduction}

\section{Co-culture}

Co-culture is the method of culturing different microorganisms, to test the effect of one culture system over another. Microorganisms are not present as pure cultures in nature. Microorganisms belonging to the same genus have shown better compatibility with each other, hence are extensively used to produce various metabolites. This can be inferred from studies on pair of microorganisms such as Bacillus cereus and Bacillus thuringiensis, Aspergillus niger MS23, and Aspergillus terreus MS105, Clostridium thermocellum ATCC 27405 and Clostridium beijerinckii ATCC 51743, Aspergillus flavus and Aspergillus penicillioides [1-4].

Natural environments are distinguished by a variety of microorganisms that interact with one another in complex ways $[5,6]$. The growth of pure culture is significant unlike its growth in a mixed culture, on account of several microbial interactions [7]. These microbial interactions can be antagonistic or synergistic, resulting in inhibited or enhanced proliferation respectively. The microbial co-cultures are living systems wherein there coexist varied interactions between two or more different microorganisms. The organisms grow with some level of contact amongst themselves within a definite, natural, or artificial media $[8,9]$. The organisms can grow independently or at the same time depending on the strength of the synergic interactions between them [10].

A positive interaction amongst the microbial populations may result in an increased growth rate of one microorganism or a group of microorganisms in a particular habitat. Enhanced production of growth-associated metabolites is possible due to synergism. For example, in a pair of microorganisms Bacillus subtilis CDBB 555 and Clostridium acetobutylicum ATCC 824 were utilized for the production of butanol, in which Bacillus subtilis CDBB 555 maintained anaerobic condition by consuming oxygen required for Clostridium acetobutylicum ATCC 824 which in turn produced butanol as the metabolite [11]. The results of co-culture work on Kluyveromyces marxianus and Saccharomyces cervisiae strains reported by Molefe [12] showed enhanced activities of both the invertase and inulinase enzymes required for the production of fructose by hydrolysis of inulin. Co-culturing fungi not only paves the way for enhancing the production of specific products but also may facilitate the detection of new biomolecules that are usually not produced when pure cultures are individually cultured [13] thus posing immense potential with industrial applications. Thus, co-culturing can be an alternate approach to improve the production of microbial bioproducts and metabolites [14].

A mixed culture could contain varieties of viruses, fungi, and bacteria, which may or may not be sustained by sharing the available resources. These consortia could be made up of species that are known or unknown. Mixed cultures are used in many microbiological processes such as in waste treatments. Combining an ideal group of enzymes can result in the most efficient biodegradation process by mixed culturing of fungi on solid substrates [15]. The study of microbial interactions can be well explained in co-culturing and mixed culturing techniques to maximize the metabolite production along with the process optimization methods [16].

\section{Microbial Bioproducts}

Microbial bioproducts have gained importance as they are eco-friendly, sustainable, easily available, and biodegradable. Enzymes, citric acid, and bioethanol produced from microorganisms are used on a large scale across various sectors [17, 18]. With the help of gene manipulations, microbial bioproducts can be cultured largely as per the need of a particular enzyme at the industrial level. Microorganisms excrete biological catalysts called enzymes during their growth and metabolism, to carry out the biochemical reactions and produce various fermentation products [16]. Microbial enzymes are classified as endo-cellular and exo-cellular enzymes. Enzymes produced in the cytoplasmic membrane or within the cell are endo-cellular enzymes. Exo-cellular enzymes are secreted by the cells and function outside the cell. These enzymes are liberated into the fermentation medium to hydrolyze and break down complex substances that are too huge to be transferred into the cell [19]. Studies have shown that many enzymes secreted by microbial fermentation for industrial applications are exocellular [11, 12]. In recent years, microbial bioproducts have acquired importance around the globe for their extensive uses in sectors like agriculture, medicine, food, chemicals, and energy [20]. Enzymes such as inulinase, amylase, protease, laccase, catalase, mannanase, pectinases, cellulase are extensively being used in various industrial sectors such as food and beverages, textile, pharma, detergents, and chemical [21]. Enzyme-mediated processes take less time, require low energy input, are eco-friendly, and are affordable. Because of these advantages and their widespread applications, microbial bioproducts are rapidly gaining interest worldwide [22]. Bioproducts research is becoming one of the most exciting topics of material science and engineering due to the increasing global demand and environmental friendliness.

\section{Solid-State Fermentation}

Solid-state fermentation (SSF) is the fermentation method that involves a solid matrix consisting minimum required amount of water. The amount of moisture in the substrate should be just enough to bear the growth and metabolism of 
the selected microbial culture [23]. The selected solid matrix (substrate) will mimic an environment suitable for the development of microorganisms [24]. The solid matrix can either act as a nutrient source or only act as matrix support which has been impregnated with appropriate nutrients that allow the growth of the microorganisms [25]. Substrates should be able to absorb and provide the required moisture without getting dissolved [26]. Determination of a significant substrate is a vital step in the SSF process. Unlike SmF (Submerged fermentation), only limited types of microorganisms i.e., fungi and yeasts, can be used for SSF due to low freely available moisture. In some cases, bacteria also have been employed [27]. Factors affecting the fermentation process include a substrate, temperature, size of substrate particle, moisture, agitation, and aeration. Another key parameter in the SSF process is the water activity $\left(\mathrm{a}_{\mathrm{w}}\right)$ of the medium for transport of solutes and water beyond the microbial cell wall and is, therefore, one of the main parameters to control fungal metabolism [23, 28-30].

\section{The Industrial Importance of SSF}

SSF is a common technique used to get various products economically. It is mainly used to produce enzymes, industrial chemicals, single-cell proteins, phenolics, food, biofuel, biologically active secondary metabolites (alkaloids, antibiotics, immune drugs, and toxins), metabolites and pharmaceutical products [31]. The morphology of many microorganisms which are composed of branched, threadlike hyphae provides conducive conditions in SSF to produce microbial secondary metabolites [32].

The beneficial features of SSF in comparison with SmF includes reduced energy consumption as it requires relatively lesser agitation, lower water requirement, and wastage as little or no free water is used in the fermentation bed, thereby leading to a reduction in the probability of contamination $[33,34]$. Other advantages of SSF include smaller size fermenters, inexpensive fermentation media, ease of handling, and the enhanced yield of metabolites [35-39]. SSF uses a wide variety of solid or semi-solid substrates which vary in properties like size, composition, porosity, mechanical resistance, and water holding capacity. The substrates used are generally industrial or agricultural wastes which are usually cheap and resistant to various contaminants. The downstream processes are less expensive as it requires lower recovery cost and less solvent. Enzymes are present in the concentrated form and are easily extractable. Disadvantages of SSF include the difficulty in maintaining and controlling the physical parameters. For example, the initial moisture level in the substrate decreases over a period and must be checked periodically.
The objective of this review is to depict the benefits of coculturing microorganisms owing to their synergism in SSF. The industrial applications of co-culturing microorganisms in a wide range of sectors such as biofuel, food, and pharmaceutical industries are elucidated. The challenges and future scope of co-culture systems are also discussed.

\section{Microorganisms and Substrates}

Microorganisms have proved to be the main source for the production of commercial products in particular enzymes. The microorganisms utilized for the biosynthesis of industrial enzymes must possess good biological activity [40]. In this review, we focus on the importance and benefits of co-cultured microorganisms. Apart from the factors affecting solid state fermentation processes, the type and extent of interactions among the co-cultured microorganisms is the one that uniquely contributes to the observed difference between single-culture and co-culture systems, with regards to the product yield and overall efficiency of the SSF process. Both organisms in the co-culture can be isolated from the same or different sources. It has been noticed that organisms isolated from the same source often show synergism and hence, are favored. Synergism can be considered as the capability of two or more microorganisms, when grown together, leading to enhanced production of metabolites in comparison with total productivity observed when grown independently [41]. Synergistic interactions between different but compatible microorganisms under alike environmental conditions have proved to produce better yields than just individual pure cultures [11, 12]. The mixed microbial cultures used under SSF have been shown to achieve elevated levels of output of abundant bio-active molecules consisting of enzymes, amino acids, vitamins, and antibiotics. Commensalism among microorganisms is considered to be a relationship wherein one microorganism is benefitted while the other is neither benefitted nor harmed in any manner [42]. This can be observed in natural environments and has been exploited in several fermentation reactions to produce varieties of foods products such as cheese. An appropriate amount of information on the progress of growth and survival of interacting microorganisms is needed to confirm whether there is no effect on one of the microorganisms while the other thrives and benefits from this kind of association [42, 43]. When each of the participating microorganisms benefits from the interaction, it can be termed as a mutualistic type of interaction. Microorganisms are bound by a common interest in such an association [16]. Synergistic interactions between microorganisms also lead to securing mutual benefits as in the case of mutualism yet differ in the fact that involving microorganisms are fully capable of surviving on their own and are not obligated to 
establish such an association [42, 44]. Generally, accessing the type of positive interaction or ensuring the compatibility between microorganisms in solid state fermentation, whether it is synergistic, mutualistic, or communalistic is a tough and crucial task that demands meticulous analysis of their growth curves. The occurrence of such positive interactions amongst microbial populations (commensalism/ mutualism/ synergism) can potentially promote their overall growth resulting in an increased production of certain growth-associated products. Only those microbial strains are selected that exhibit synergism, mutualism, or commensalism [42]. Compatibility analysis is carried out by comparing the growth curves of both the microorganisms first in a single culture and then in a mixed culture. Fossi et al. [16] critically analyzed the growth curves of both pure and mixed cultures of Bacillus amyloliquefaciens 04BBA15 and Saccharomyces cerevisiae for the production of $\alpha$-amylase, which showed a notable increase in growth of $S$. cerevisiae while the growth of B. amyloliquefaciens 04BBA15 was unaffected when grown together. The commensalism relationship between these species could be justified by the fact that glucose released into the medium as a result of starch hydrolysis by B. amyloliquefaciens was consumed by non-starch utilizing S. cerevisiae for its efficacious growth. Fossi et al. [16] also reported mutualism of two strains by comparing the growth profiles of both pure and mixed cultures of Saccharomyces cerevisiae and Lactobacillus fermentum 04BBA19, which showed a significant rise in the growth of each of the two strains when cultured together. The $\alpha$-amylase activity of $L$. fermentum released glucose which was subsequently consumed by $S$. cerevisiae thereby suppressing the inhibitory effect of excess glucose [16].

In SSF, insoluble solid substrates act not only as a nutrient source but also as solid support for the upsurge of microbes. Nearly all the substrates that are employed in SSF are inexpensive agricultural residues generated from agro-industrial activities, those of which are otherwise under-utilized. Fungi with their extensive network of hyphae are capable of growing over and utilizing the agro-industrial waste conveniently as it mimics their natural habitat. Nutrient-rich substrates decompose steadily which can be used for a longer time and be reprocessed later. This diminished the need for replenishing substrates under SSF [45].

One of the prime components that indifferently affect single cultures and co-culture systems under the operation of SSF is the property of the solid substrate utilized. Factors such as moisture level and particle size are essential for the optimal microbial activity and growth on a specific substrate $[46,47]$. The particle size of the solid substrate directly influences its surface area to volume ratio and hence indirectly affects the extent to which microorganisms are in contact with the nutrient and oxygen diffusivity [48]. Smaller particle size contributes to a larger surface area to volume ratio which in turn provides a higher contact between microorganisms and nutrients but hinders the diffusion of oxygen. On the other hand, larger particles having a smaller surface area to volume ratio lessen the contact with nutrients but aid excellent oxygen diffusivity [27]. Therefore, appropriate particle size must be chosen to ensure optimum mycelial growth, oxygen, and nutrient supply [49]. The metabolic activities of microbial cultures and accordingly the resultant products have been observed to be affected by higher and lower initial moisture levels [50]. This can be understood by the fact that lower moisture levels result in the poor dissolution of nutrients from the solid substrate and increased water tension. Likewise, it has been reported that higher moisture levels lead to reduced porosity, poor gas exchange, the disappearance of particulate structure, the occurrence of stickiness, and increased formation of an aerial type of mycelium [51]. As per the above discussions, these factors are applicable for all microorganisms including co-cultured microorganisms. Ideally, a solid substrate used in SSF must be capable of acting as physical support, source of essential nutrients needed for the growth of all desired microorganisms involved, and as an appropriate inducer in case of enzyme production, all of which is difficult to be satisfied by a single substrate. Thus, this bottleneck can be overcome by the utilization of mixed substrates under SSF for co-cultures [52] which have been shown to enhance the product yield adequately [53]. While employing mixed substrates under SSF to nurture the given microbial co-culture, their nature and proportions are deciding factors for achieving an optimal product yield [54]. Some of the substrate combinations such as pineapple peels, banana peels, and papaya peels [55], corn cob and Bermuda grass [56], wheat bran, pulse husk, and mustard peel [57], freeze-dried okara and pork lard [58] are utilized to facilitate better nutrition for growth and thus improving the yield of the product.

Table 1 depicts that $\alpha$-amylase can be produced either from a bacterial co-culture of Bacillus thuringiensis and Bacillus cereus [1] or by employing fungal co-cultures of Phanerochaete chrysosporium and Schizophyllum commune [55] or Aspergillus niger GS1 and Trichoderma reesei [56]. Cellulase enzymes can be synthesized by using various combinations of not only fungal co-cultures as mentioned [10, 59] but also from a bacteria-fungi co-culture of BacillusTrichoderma [60]. It can be deduced that a particular product can be obtained by co-culturing different combinations of microorganisms. This shows the existence of synergism between several microorganisms. Fungal co-cultures are widely studied when compared with bacterial co-cultures in SSF as it supports low water content which is favorable for the growth of fungi. Aspergillus sp. and Trichoderma $s p$. are extensively used for co-culturing. These fungi are isolated from diverse sources to produce a broad spectrum of products under SSF. 
Table 1 Sources and substrates utilized for microbial co-culture under solid state fermentation

\begin{tabular}{|c|c|c|c|}
\hline Sources & Substrate & Product & References \\
\hline Bacillus thuringiensis and Bacillus cereus & Wheat bran & $\alpha$-amylase & [1] \\
\hline $\begin{array}{l}\text { Aspergillus terreus MS105 and Aspergil- } \\
\text { lus niger MS } 23\end{array}$ & Lime peels & Cell wall degrading enzymes & {$[2]$} \\
\hline $\begin{array}{l}\text { Clostridium beijerinckii ATCC } 51743 \text { and } \\
\text { Clostridium thermocellum ATCC } 27405\end{array}$ & Corn stover and silvergrass (miscanthus) & $\begin{array}{l}\text { Ethanol, acetic acid, lactic acid, butyric } \\
\text { acid, acetone and butanol }\end{array}$ & {$[3]$} \\
\hline $\begin{array}{l}\text { Aspergillus penicillioides and Aspergillus } \\
\text { flavus }\end{array}$ & Wheat bran & Xylanase, Fpase, $\beta$-xylosidase, CMCase & {$[4]$} \\
\hline $\begin{array}{l}\text { Trichoderma reesei, Aspergillus oryzae, } \\
\text { and Phanerochaete chrysosporium }\end{array}$ & $\begin{array}{l}\text { Soyabean cotyledon fiber and distiller's } \\
\text { dried grains }\end{array}$ & Xylanase, Cellulase & {$[10]$} \\
\hline $\begin{array}{l}\text { Aspergillus niger ATCC } 10864 \text { and } \\
\text { Trichoderma reesei } \mathrm{LM}-1\end{array}$ & Extracted sweet sorghum silage & Cellulase, Xylanase & {$[15]$} \\
\hline $\begin{array}{l}\text { Cladosporium sphaerospermum, Aspergil- } \\
\text { lus flavus and Epicoccum purpurascens }\end{array}$ & Sawdust and wheat bran & Xylanase & {$[54]$} \\
\hline $\begin{array}{l}\text { Phanerochaete chrysosporium and Schizo- } \\
\text { phyllum commune }\end{array}$ & $\begin{array}{l}\text { Pineapple peels, banana peels and papaya } \\
\text { peels }\end{array}$ & $\alpha$-amylase, Cellulase & {$[55]$} \\
\hline $\begin{array}{l}\text { Trichoderma reesei and Aspergillus niger } \\
\text { GS1 }\end{array}$ & Corn cob and Bermuda grass & Fpase, Amylase, Xylanase & {$[56]$} \\
\hline Trametes hirsuta and Phanerochaete sp & Wheat bran, pulse husk and mustard peel & Laccase, Pectinase & {$[57]$} \\
\hline $\begin{array}{l}\text { Aspergillus penicillioides and Aspergillus } \\
\text { flavus }\end{array}$ & Freeze-dried okara and pork lard & $\begin{array}{l}\text { Bio valorisation of the product with anti- } \\
\text { microbial activity and antioxidant }\end{array}$ & {$[58]$} \\
\hline $\begin{array}{l}\text { Penicillium citrinum NCIM } 768 \text { and } \\
\text { Trichoderma reesei NCIM } 1186\end{array}$ & Wheat bran & Cellulase & {$[59]$} \\
\hline Bacillus-Trichoderma co-culture & Palm kernel cake & Cellulase & {$[60]$} \\
\hline $\begin{array}{l}\text { Eupenicillium crustaceum and Pacelio- } \\
\text { myces sp. }\end{array}$ & Paddy straw & $\begin{array}{l}\text { Endoglucanase, Xylanase, Filter paperase, } \\
\beta \text {-glucosidase }\end{array}$ & {$[91]$} \\
\hline Trichoderma reesei and Aspergillus niger & Kinnow fruit pulp and peel & Filter paperase, CMCase, $\beta$-glucosidase & {$[92]$} \\
\hline $\begin{array}{l}\text { Trichoderma reesei and Aspergillus } \\
\text { fumigatus }\end{array}$ & Dioscorea zingiberensis (a species of yam) & Diosgenin & {$[90]$} \\
\hline $\begin{array}{l}\text { Trichosporonoides oedocephalis and Peni- } \\
\text { cillium italicum }\end{array}$ & Orange peels & Mannanase & [93] \\
\hline $\begin{array}{l}\text { Daldinia concentrica and Xylaria poly- } \\
\text { morpha }\end{array}$ & Bean husks & $\begin{array}{l}\text { Decolorization and the detoxification of } \\
\text { Cibacron brilliant red 3B-A }\end{array}$ & [94] \\
\hline Rhizopus stolonifera and Aspergillus niger & Orange peel & Citric acid & {$[17]$} \\
\hline $\begin{array}{l}\text { Trichoderma sp. And Saccharomyces } \\
\text { cerevisiae }\end{array}$ & Sweet potato flour & Bioethanol & [77] \\
\hline $\begin{array}{l}\text { Aspergillus ornatus and Alternaria } \\
\text { alternata }\end{array}$ & Apple pomace & Citric acid & {$[18]$} \\
\hline
\end{tabular}

The substrates listed in Table 1 are a wide variety of cost-effective solid substrates and are easily available. The widely used substrates are agro-industrial wastes mainly wheat bran, fruit peels, and sugarcane bagasse. Most of these compounds are polymeric molecules and constitute a rich source of nutrients. The choice of considering crude or purified substrates for enzyme production in SSF also has an impact on the outcome [2]. In the case of xylanase production, the use of purified substrates such as xylan accounted for $0.007 \mathrm{~g}$ total reducing sugar whereas banana peels being a natural substrate showed $0.28 \mathrm{~g}$ per $0.5 \mathrm{~g}$ of substrate. Generally, the substrates used are heterogeneous and sparingly soluble or insoluble in water. Most of the time, pre-treatment of substrates is required to enhance their accessibility before it is used for the fermentation process [61]. Pretreatment methods can be either physical, chemical, biological, or a combination of these methods [62-64]. The nature of the substrate greatly affects the choice of the pretreatment method. Physical methods include grinding, milling, densification, irradiation, and high temperature which can improve product yields by increasing the available surface area and size of pores [65-67]. Chemical type of pretreatment widely involves the use of acids, alkali, ammonia, and related methods [68]. Biological methods of pretreatment include enzymatic methods of degradation. It has proven to be an inexpensive, low-energy, safe and eco-friendly way to remove lignin from lignocellulose [69]. Corn stover substrates used for butanol production were subjected to the 
biological type of pre-treatment utilizing solid state cultivation of Phanerochaete chrysosporium ATCC MYA-4764 to degrade the lignin content. This is because the butanolproducing bacterial co-culture is incapable of catabolizing complex lignocellulosic substrates [3]. Thus, such pretreatment techniques hold immense potential to improve the overall process efficacy and lessen the cost through extensive research and development [70].

\section{Fermentation and Optimization Techniques}

\section{Fermentation Process}

The factors that affect the fermentation process of co-culture are the compositions of fermentation media, water activity, moisture content, inoculum volume, sequence of inoculation, incubation temperature, and nature of the substrate. These physicochemical factors contribute immensely to the production of the desired products [71]. Pre-treatment of the substrate is recommended as it enhances its properties as described in the previous section. Industrial SSF processes are carried out in trays, packed-bed, horizontal drum, and fluidized-bed reactors [33].

The major role of SSF bioreactors is to incorporate the substrate, maintain aseptic conditions, meet the oxygen requirement for aerobic fermentation, monitor the heat transfer and mass transfer effects and regulate the environmental conditions to enhance the growth of microorganisms and therefore improve the product yield [72, 73]. Figure 1 explains the types of lab-scale, pilot, and industrial-scale bioreactors. It also explains the various aeration strategies used in these different bioreactors.

The bioreactors in group 1 (Fig. 1, upper-right quadrant) have trays stacked one on top of the other and consist of a chamber. The air blown into the chamber is conditioned and controlled. Trays used are usually made of wood, metal, plastic, or bamboo. The agitation is generally done by hand

\begin{tabular}{|c|c|c|c|}
\hline \multirow{2}{*}{$\begin{array}{l}\text { Aeration } \\
\text { strategy }\end{array}$} & \multicolumn{3}{|c|}{ Agitation strategy } \\
\hline & $\begin{array}{l}\text { No mixing (or very } \\
\text { infrequent) }\end{array}$ & \multicolumn{2}{|c|}{ Continuous mixing or frequent intermittent mixing } \\
\hline $\begin{array}{l}\text { No forced } \\
\text { aeration } \\
\text { (air passes } \\
\text { around bed) }\end{array}$ & 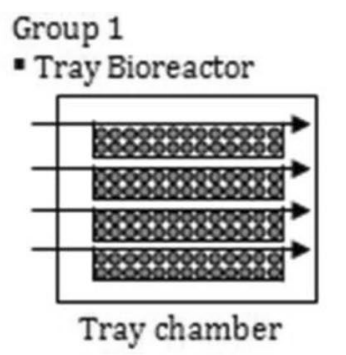 & \multicolumn{2}{|l|}{$\begin{array}{l}\text { Group } 3 \\
\text { - Rotating drum bioreactors } \\
\text { - Stirred drum bioreactors }\end{array}$} \\
\hline $\begin{array}{l}\text { Forced } \\
\text { aeration } \\
\text { (air blown } \\
\text { forcefully } \\
\text { through the } \\
\text { bed) }\end{array}$ & $\begin{array}{l}\text { Group } 2 \\
\text { - Packed bed } \\
\text { bioreactors } \\
\text { - Intermittently stirred } \\
\text { packed-beds }\end{array}$ & $\begin{array}{l}\text { Group } 4 \\
\text { - Stirred-bed bioreactors } \\
\text { - Rocking drum bioreactors } \\
\text { - Gas-solid fluidised bioreactors } \\
\text { Gas-solid fluidised bed Stirred bed }\end{array}$ & 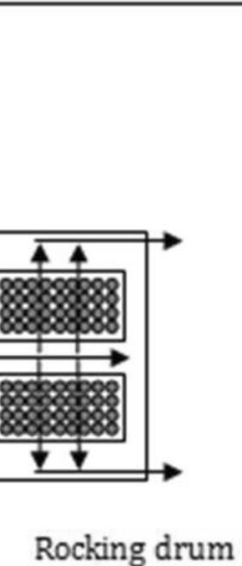 \\
\hline
\end{tabular}

Fig. 1 Agitation strategy of bioreactors under solid state Fermentation [33] 
and hence is not very frequent. The chamber is open at the top and has perforated bottoms to increase the accessibility to oxygen. Group 2 (Fig. 1, lower-left quadrant) is a characteristic packed-bed bioreactor consisting of a column of rectangular or cylindrical cross-section, in which the air is blown up through the base plate. Such bioreactors are typically oriented vertically with a perforated base plate at the bottom which supports the substrate bed. The bioreactors in group 3 (Fig. 1, upper-right quadrant) are generally horizontal and consist of a drum of a cylindrical cross-section. The whole drum rotates around its central axis to mix the substrate bed in rotating drums. As for the stirred drums, the bioreactor body remains stationary and paddles or scrapers mounted on a shaft running along the central axis of the bioreactor rotate within the drum. The mixed and forcefully aerated bioreactors in group 4 (Fig. 1, lower-right quadrant) can be operated with continuous or discontinuous mixing [33].

The selection criteria of bioreactors for single cultured and co-cultured organisms depends on the optimum operating parameters such as type of microorganisms used, oxygen requirement, the resistance of the microorganisms to mechanical agitation, moisture level, and temperature $[30,39]$. The same bioreactors can be used for both the above-mentioned types of organisms used. Parameters like diffusion, pore size are applicable for single as well as for co-cultured systems. The different types of industrial and pilot-scale bioreactors are unmixed SSF bioreactors with and without forced-air circulations, intermittently mixed-bed bioreactors with air circulation, and continuously mixed SSF bioreactors with air circulation [30, 39, 72, 73]. The features and limitations of some commonly used bioreactors under SSF are tabulated in Table 2. There are no studies reported on bioreactors for SSF using co-culture systems. Research on the design and operation of bioreactors for SSF with coculture offers an opportunity for future studies.

Apart from the above-mentioned bioreactors (Fig. 1), rotating disc reactors, stirred drum bioreactors, zymotis packed-bed bioreactor, spouted-bed bioreactor, air pressure pulsation solid state bioreactors, and immersion bioreactors are used under controlled conditions. The zymotis bioreactor is grouped as a packed bed fermenter as the moist solid substrate is packed into the rectangular box fermenter. It is a novel large-scale solid-state fermenter, that not only can control various vital process parameters such as temperature, moisture content, and aeration but is also equipped with a novel cooling system for the easy removal of the huge amount of metabolic heat generated. Zymotis with its simple design and ease of operation has shown abundant potential in encouraging SSF technologies for industrial utilization and thus directing the harvest of several economical merits of SSF. The main advantages are that it overcomes problems like heat removal and leads to the stable and

Table 2 List of broadly used solid state fermentation bioreactors' features and limitations [33, 72]

\begin{tabular}{|c|c|c|}
\hline Bioreactor & Bioreactor features & Limitations \\
\hline Bench scale, Erlenmeyer flask, petri dish & $\begin{array}{l}\text { Quicker optimization of the experimental and } \\
\text { process values } \\
\text { Cheap, small amount of substrate used and lower } \\
\text { risk of contamination } \\
\text { Passive aeration, easy regulation of airflow rate } \\
\text { and temperature }\end{array}$ & $\begin{array}{l}\text { Heat accumulation, non-mixed and inadequate } \\
\text { aeration }\end{array}$ \\
\hline \multirow[t]{2}{*}{ Tray bioreactors } & $\begin{array}{l}\text { Substrate is spread on the reactors made of flat } \\
\text { trays forming a thin layer }\end{array}$ & $\begin{array}{l}\text { Required many trays and therefore larger area and } \\
\text { volume which makes it tedious and extremely } \\
\text { unattractive for industrial scale }\end{array}$ \\
\hline & $\begin{array}{l}\text { Aeration is maintained through airflow at con- } \\
\text { stant temperature and pressure }\end{array}$ & Non-uniform growth \\
\hline \multirow[t]{2}{*}{ Packed-bed bioreactors } & $\begin{array}{l}\text { The substrate is retained on the perforated base } \\
\text { of the main body of the bioreactor }\end{array}$ & $\begin{array}{l}\text { Difficulties for sampling, scaling up problems, bed } \\
\text { caking, non-uniform growth, low heat removal } \\
\text { and labour-intensive }\end{array}$ \\
\hline & $\begin{array}{l}\text { A jacket is fitted around the bioreactor to adjust } \\
\text { the temperature to the desired value }\end{array}$ & \\
\hline Horizontal drum bioreactors & $\begin{array}{l}\text { Mixing is achieved by the agitation of baffles and } \\
\text { paddles } \\
\text { Mixing of the substrate and proper aeration }\end{array}$ & $\begin{array}{l}\text { Due to agitation, the product and the inoculum can } \\
\text { get damaged } \\
\text { Only } 30 \% \text { of the drum is filled, otherwise mixing } \\
\text { is not efficient }\end{array}$ \\
\hline Fluidized-bed bioreactor & $\begin{array}{l}\text { The reactor uses continuous agitation with forced } \\
\text { air } \\
\text { This prevents the aggregation and adhesion of } \\
\text { solid particles } \\
\text { High heat and mass transfer rate }\end{array}$ & $\begin{array}{l}\text { The final yield of the product can be affected due } \\
\text { to inoculum damage and heat build-up } \\
\text { Difficult to fluidize large, sticky and coarse parti- } \\
\text { cles }\end{array}$ \\
\hline
\end{tabular}


controlled performance of the bioreactor [74]. Whereas in the spouted-bed reactor, only a part of the substrate bed is fluidized as air is blown upwards through the central axis of the bed. The solid slips to the bottom of the bioreactor due to its sloped slides because of the vigorous contact between the solid substrate particles and the gas (Fig. 2) [75]. It has reduced power requirements when compared with fluidizedbed systems. It is good at handling large, non-uniformly sized, coarse, and sticky particles. The advantage of the spouted-bed bioreactor is that it stops particle accumulation created by high-speed collisions in the spouted bed's core region $[33,76]$. However, the tray bioreactor is most used for enzyme production and is the most suitable for the scale-up process $[31,77,78]$.

\section{Optimization Techniques}

Optimization of process parameters plays a very important role in any type of fermentation process to enhance the yield of microbial metabolite [71]. Various optimization techniques are adopted to find the optimum values of process parameters. The most used optimization techniques are Evolutionary operation factorial design technique (EVOP), Plackett-Burman's Design (PBD), one factor at a time (OFAT), central composite design (CCD), Box-Behnken design (BBD), artificial neural network (ANN) and genetic algorithm (GA). Design of the fermentation process is a tedious task and each optimization technique used would show its impact on the result of the process. Generally, these techniques are used in combinations to obtain the required outcome. The simple and the most preferred optimization technique is OFAT, wherein only one factor is changed at a time by retaining the remaining operational parameters [79]. PBD, a two-level design is phenomenal in eliminating the non-contributing parameters and helps in screening the process factors [80]. Factorial design technique employs

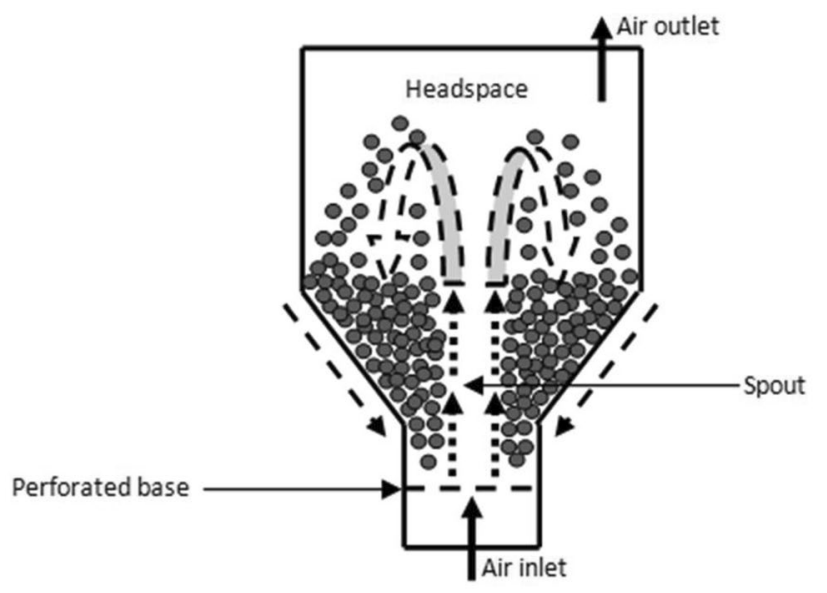

Fig. 2 Spouted-bed bioreactor [33] independently varying levels of factors or parameters, each factor at two or more levels whereas evolutionary operation uses factorial design to better the yield. EVOP being the hybrid child of factorial design and evolutionary operation possesses the capacity to both, design experiments with $n$ parameters and to systematically analyze the experimental results and provide conclusive data on optimum fermentation conditions [79].

Table 3 depicts that Bacillus cereus and Bacillus thuringiensis co-culture yielded an amylase production of $44.0 \mathrm{U} / \mathrm{mL} / \mathrm{min}$ using wheat bran as the substrate in SSF [1] whereas Aspergillus niger GS1 and Trichoderma reesei fungal co-culture provided a profound amylase yield of 181.4 U/g.h using bermudagrass and corn cob used as the substrate [56]. As mentioned before, it can be observed that under SSF, bacterial co-cultures give comparatively lesser yield than fungal co-cultures owing to the fungal growth favorable environment of SSF. To achieve better growth and higher enzyme production, the inoculation sequence of different microorganisms can be studied to recognize the one that provides the best interaction among the microorganisms. Thus, the order in which the microorganisms are inoculated for co-culturing purposes is also one of the deciding factors to get a higher yield [10].

Co-culture of microorganisms with optimization techniques is a strategy to enhance enzyme production. Mostafa et. al. [54] reported the fungal co-culture for the production of xylanases using three organisms $C$. sphaerospermum, $A$. flavus, and E. purpurascens under SSF with sawdust and wheat bran (1.5:1.5) for a higher yield. The three co-cultured organisms produced a higher activity of xylanases when compared to the activity observed under single culture. The three co-cultured organisms increased the enzyme activity by $55.41 \%, 63.31 \%$, and $156.22 \%$ when compared to $C$. sphaerospermum, A. flavus, and E. purpurascens respectively when grown individually. The synergic interactions between these three strains aided the production of xylanases [54]. According to the study reported by Lio and Wang [10], Trichoderma resei and Phanerochaete chrysosporium were inoculated and incubated for $36 \mathrm{~h}$, followed by Aspergillus oryzae for an additional $108 \mathrm{~h}$. This inoculation scheme resulted in the highest xylanase activity of $399.2 \mathrm{IU} / \mathrm{g}$ compared to other fungus combinations using distiller's dried grains with solubles (DDGS) as a substrate under SSF [10].

\section{Purification}

Purification is a crucial step in product recovery and the process starts with the separation of cells from the fermentation broth to recover desired metabolites. The purification step plays a major role in the yield of the metabolite and the separation of byproducts. Depending on the nature and the purity of the metabolite produced by an organism, the 


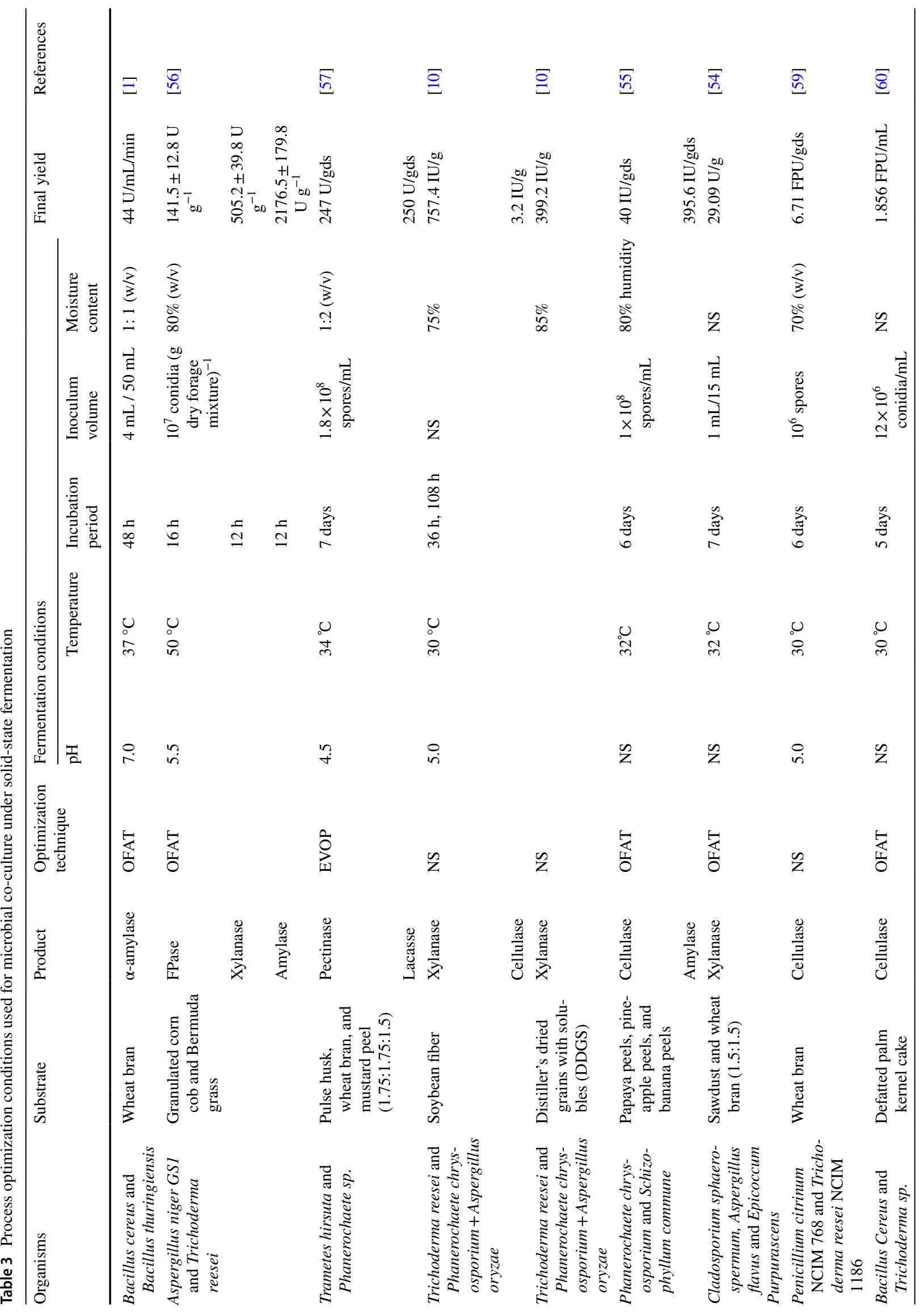




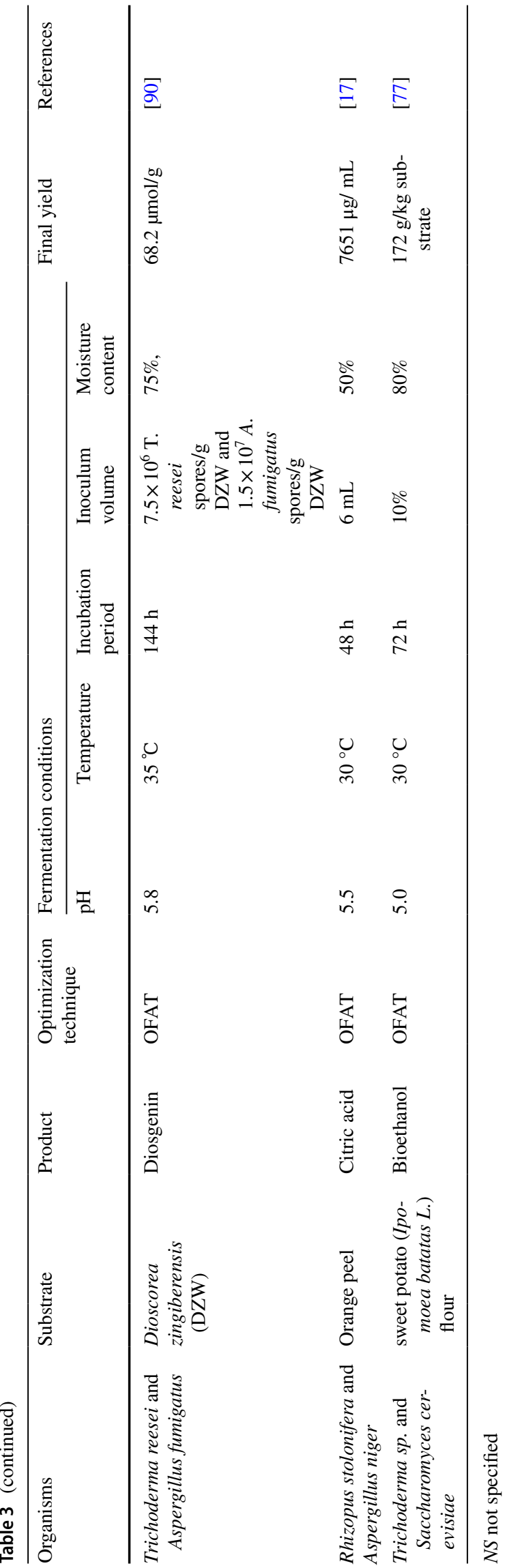

various options available for separation include filtration, centrifugation, precipitation, dialysis techniques [81]. Ultrafiltration, chromatography, and electrophoresis techniques can be employed for highly purified products $[14,82]$.

Ammonium sulfate precipitation is considered a crude separation step. It is generally used in the initial stages of purification, followed by dialysis and a combination of chromatographic steps $[81,83]$ as mentioned in Fig. 3 and Table 4. The dialysis step is employed to purify the crude metabolite. Usually, this part of downstream processing operation includes a series of sequential chromatography steps, but several pre-treatment methods (e.g., membrane filtration, precipitation, aqueous two-phase partitioning) can also be used either alone or in combination to improve the performance of purification. Chromatography is being widely used in industries as it has proved to be very efficient due to its high-resolution capacity. Size exclusion, anion, and cation exchange chromatography are the various chromatographic techniques used to further purify the product obtained. Several purification steps can be capped to three to maximize the purity and yield of the products [84].

\section{Applications}

An extensive range of technological operations is observed in the co-culture systems in numerous industries such as food, textile, pharmaceutical, polymer, biofuel, paper, and pulp industries. Various applications of the same are mentioned in Table 5. A mixture of co-culturally produced hydrolytic enzymes such as xylanase, amylase, and cellulose is useful for animal feed improvement as it breaks down the fibrous substrates and improves its digestibility, especially in non-ruminant animals $[10,56,85]$. Cellulase and hemicellulase enzyme mixture inclusion aids in the utilization of fibrous cellulosic part of feed resulting in increased starch saccharification to sugars and their successive fermentation to produce products like ethanol [86]. The enzyme tannase is mainly used for the synthesis of an antibacterial and antifolate drug trimethoprim owing to the enzymatic capability by which it hydrolysis gallotannin to gallic acid [87]. $\beta$-mannanases inclusion in the manufacturing of chocolate, instant coffee, and cocoa liquor aids by decreasing the viscosity of extracts thereby lowering drying costs [88]. Sustainable processes like the development of highvalue compounds through biomass transformation and the development of biorefinery platforms are possible due to the technology of co-culture systems [89].

\section{Challenges in Microbial Co-culture Method}

Practical aspects should be considered systematically while depicting the natural phenomenon of the co-culture system in various bio-manufacturing industries. The properties of 
the microorganism used in the pilot and industrial-scale bioreactors depend on its oxygen requirement, its resistance to mechanical steering, and the temperature range. Contamination is one of the major challenges faced while co-culturing microorganisms [30, 39]. While selecting the organisms, it is preferred that organisms that show maximum synergism among them should be selected and worked upon. If there is antagonism, one organism could suppress or interfere with the normal functioning of the other organism. Culturing several species together sometimes results in unstable systems. This happens due to multiple pathways of each organism which makes it difficult to analyze, monitor, and
Fig. 3 Downstream processes of some bioproducts [42-44]

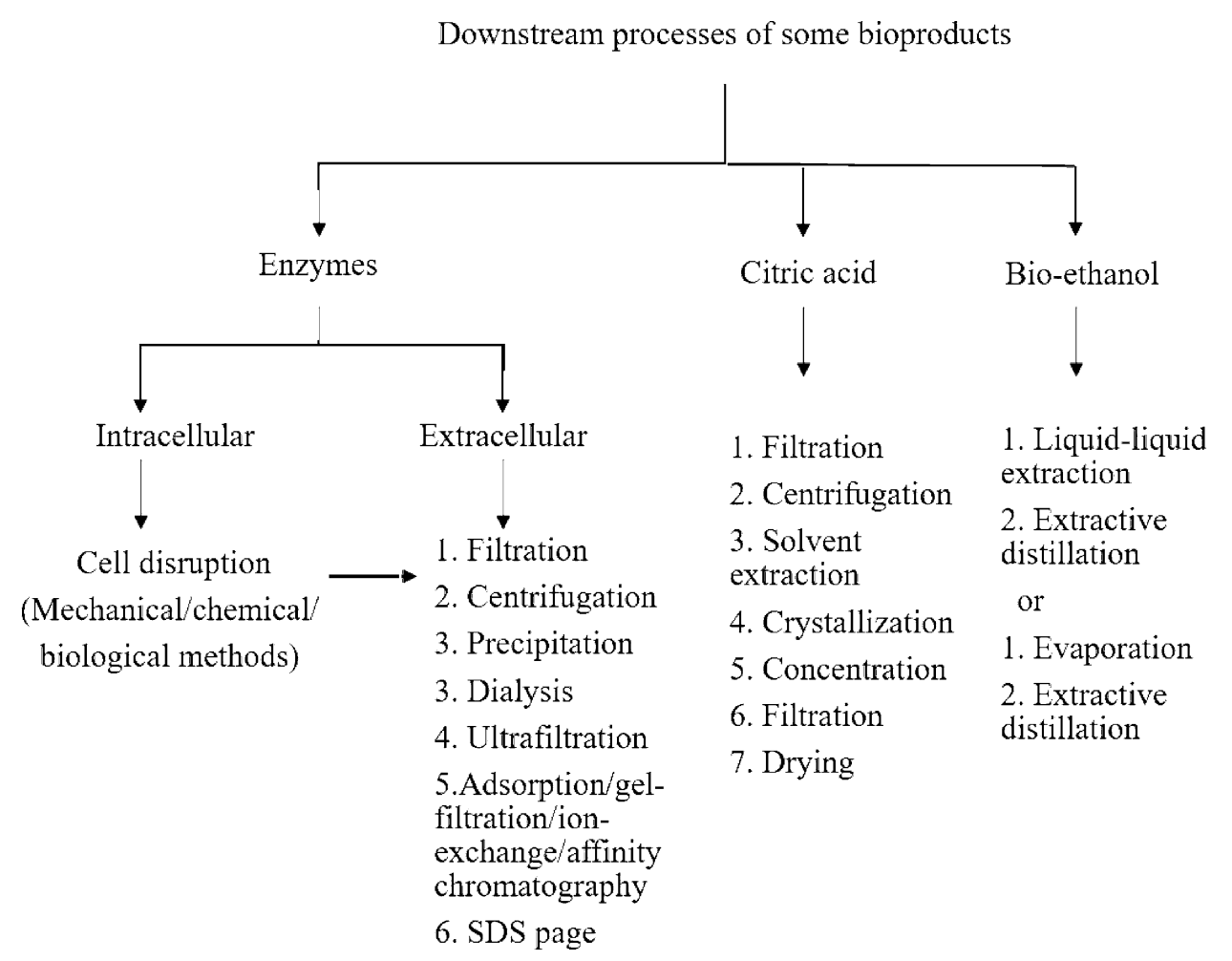

Table 4 Techniques used for purification of enzymes produced by microbial co-culture under SSF

\begin{tabular}{|c|c|c|c|}
\hline Product & Purification methods & Purification fold & References \\
\hline Tannase & Ammonium sulfate precipitation, DEAE Sephadex A-50 column chromatography & 1.33 & [95] \\
\hline Protease & Ammonium sulfate precipitation, centrifugation & 3.3 & [96] \\
\hline Pectinase & $\begin{array}{l}\text { Centrifugation, ammonium sulfate precipitation, lyophilization, gel filtration column } \\
\text { chromatography }(2 \times 20 \mathrm{~cm})\end{array}$ & 5.59 & [97] \\
\hline Galacto oligosaccharides & $\begin{array}{l}\text { Simulated moving bed (SMB) chromatography, like selective adsorption in activated } \\
\text { carbon, selective precipitation with ethanol }\end{array}$ & NS & [98] \\
\hline Xylanase & Anion exchange chromatography, SDS page & 2.35 & [99] \\
\hline Lacasse & $\begin{array}{l}80 \% \text { ammonium sulphate fractionation, dialysis, DEAE liquid column chromatogra- } \\
\text { phy, SDS page }\end{array}$ & 1.23 & {$[100]$} \\
\hline Inulinase & Ammonium sulfate precipitation, ion-exchange chromatography & NS & {$[101]$} \\
\hline Amylase & Ammonium sulfate precipitation, centrifugation, dialysis, SDS page & 1.41 & {$[102]$} \\
\hline Cellulase & $\begin{array}{l}\text { Ammonium sulfate precipitation, DEAE-cellulose column chromatography, CM- } \\
\text { cellulose column chromatography }\end{array}$ & 9.7 & [103] \\
\hline$\beta$-mannanase & $\begin{array}{l}\text { Ultrafiltration, fast protein liquid chromatography (FPLC), concentration, centrifuga- } \\
\text { tion, Sephacryl S-200HR (16/60) column, SDS page }\end{array}$ & 10.3 & [104] \\
\hline$\beta$-glucosidase & $\begin{array}{l}\text { Ammonium sulfate precipitation, dialysis, centrifugation, gel filtration on Sephadex } \\
\text { G-75 }\end{array}$ & 86 & {$[105]$} \\
\hline
\end{tabular}

$N S$ not specified 
interpret the results. The microbial growth curve should be observed, and measures should be taken that one organism does not outgrow the other [16]. Even slight variations in the co-culturing system destabilize their synergistic balance and modify the behavior of the organisms which eventually leads to loss of product. Identifying the metabolites, proteins, and peptides released by all the organisms within a co-culture helps to understand the population dynamics and underlying communication to develop a successful industrial consortium [67].

\section{Future Scope}

Co-culturing of microorganisms can be used to study both synthetic as well as natural cell-cell interactions. By understanding these interactions, new pathways for organisms that are difficult to culture can be re-engineered [8]. Strategies for microbial strain improvement can prove beneficial to promote the utilization of complex substrates, their efficient assimilation, and to minimize the formation of undesired by-products of the fermentation process. In addition, recombinant or mutated strains can be made to have increased tolerance to environmental variations. Mutant microbial strains may also be manipulated to have better synergy with each other. Co-culturing these will in turn provide improved product yields. Epigenetics modifications can be done to modulate DNA or histones for initiating the transcription of the silent genes. DNA methyltransferase inhibitors or histone deacetylase are epigenetic modifiers that are used to treat microorganisms. Accumulation of new compounds is possible due to this modulation [68]. Industrial products like pharmaceutical drug precursors, biofuels, amino acids, vitamins, valuable pigments, and antibiotics can also be obtained by co-culturing microorganisms $[9,90]$. As stated in the section "Fermentation process", there are no studies reported on bioreactors for SSF using co-culture systems. Research on the design and operation of bioreactors for SSF with co-culture offers an opportunity for future studies.

\section{Conclusion}

Co-cultured organisms have proved to be beneficial over mono cultured organisms. Fungal co-cultures are more beneficial and hence widely used over bacterial co-cultures. An extensive range of fungal and bacterial organisms can be cocultured under different conditions if they have good synergy between them. The pharmaceutical, industrial, food, textile sectors are benefited from the products of co-cultured microorganisms. As mentioned above, not only enzymes but also other products are being produced using co-culture through SSF such as citric acid, bio-butanol, and ethanol. Specific purification protocols are tailored to increase the yield and purity of the products obtained. The process conditions and protocols for a particular product are optimized based on the type of organism, substrate, and other process variables.

Table 5 Applications of bioproducts in various industries produced under SSF using co-culture

\begin{tabular}{|c|c|c|c|}
\hline Industry & Enzyme & Products & References \\
\hline \multirow[t]{6}{*}{ Food Industry } & Lacasse and pectinase & Modify the colour and increase the yield of drinks like beer, wine & {$[106-108]$} \\
\hline & Xylanase, amylase and cellulase & To improve animal feed digestibility & {$[10,56,86]$} \\
\hline & Citric acid, lacasse and pectinase & To improve existing flavour and colour & {$[17]$} \\
\hline & B-mannanases & Clarification of fruit juices and extraction of oils & {$[109]$} \\
\hline & Cellulose and hemicellulose & Increased ethanol production & {$[86,87]$} \\
\hline & $\beta$-mannanases & Production of chocolate, instant coffee and cocoa liquor & {$[89]$} \\
\hline \multirow[t]{4}{*}{ Pharmaceutical Industry } & Tannase & Synthesis of an antifolate and antibacterial drug trimethoprim & {$[88]$} \\
\hline & Diosgenin & Synthesis of oral contraceptives, sex hormones and other steroids & {$[90]$} \\
\hline & $\beta$-mannanases & Production of single-cell proteins & {$[90]$} \\
\hline & Citric acid & To increase existing flavours & {$[17]$} \\
\hline \multirow[t]{3}{*}{ Textile Industry } & Lacasse and pectinase & $\begin{array}{l}\text { Finishing, washing off treatment, bio-sourcing, dyeing, bio bleach- } \\
\text { ing and printing }\end{array}$ & {$[90,110]$} \\
\hline & B-mannanases & Facilitates bio-bleaching & [111] \\
\hline & Xylanase and laccase & Total degradation of lignocellulose for its effective use & {$[2]$} \\
\hline Biofuel Industry & Bioethanol and butanol & $\begin{array}{l}\text { Both used as a green alternative to fossil fuels. Butanol is an excep- } \\
\text { tional fuel as it is miscible with diesel and gasoline fuel, has high } \\
\text { calorific value, is less miscible with water and has a lower vapor } \\
\text { pressure }\end{array}$ & {$[18,112-114]$} \\
\hline Polymer Industry & Lacasse and pectinase & $\begin{array}{l}\text { Generation of monomers, cross-linking of the monomers and } \\
\text { synthesis of biopolymers }\end{array}$ & {$[115,116]$} \\
\hline Wastewater Treatment & Lacasse & Biodegradation as well as detoxification of the pollutant & {$[94]$} \\
\hline
\end{tabular}


Various types of bioreactors are used for SSF depending on the nature of the organisms and products. The bioreactors are each designed and operated differently for each process. Apart from the generally used bioreactors, some uncommon bioreactors such as zymotis, fluidized beds, and spouted beds are reviewed. Bioreactors assist in diversifying the protocol which can result in increased production and less wastage.

Author contributions GP and DB contributed to the data collection, analyzed data, and wrote the original draft. RBM designed and supervised the study. SS also designed the study and was involved in data curation and drafting the manuscript. All authors read and approved the final manuscript.

Funding Open access funding provided by Manipal Academy of Higher Education, Manipal. Not applicable.

Data availability The datasets used and/or analyzed during the current study are available from the first author on reasonable request.

\section{Declarations}

Conflict of interest The authors declare that they have no competing interests.

Ethical approval Not applicable.

Consent to participate Not applicable.

Consent for publication Not applicable.

Open Access This article is licensed under a Creative Commons Attribution 4.0 International License, which permits use, sharing, adaptation, distribution and reproduction in any medium or format, as long as you give appropriate credit to the original author(s) and the source, provide a link to the Creative Commons licence, and indicate if changes were made. The images or other third party material in this article are included in the article's Creative Commons licence, unless indicated otherwise in a credit line to the material. If material is not included in the article's Creative Commons licence and your intended use is not permitted by statutory regulation or exceeds the permitted use, you will need to obtain permission directly from the copyright holder. To view a copy of this licence, visit http://creativecommons.org/licenses/by/4.0/.

\section{References}

1. Abdullah, R., Naeem, N., Aftab, M., Kaleem, A.: Enhanced production of alpha amylase by exploiting novel bacterial co-culture technique employing solid state fermentation. Iran. J. Sci. Technol. Trans. A (2016). https://doi.org/10.1007/s40995-016-0015-x

2. Rehman, S., Aslam, H., Ahmad, A., Khan, S.A., Sohail, M.: Production of plant cell wall degrading enzymes by monoculture and co-culture of Aspergillus niger and Aspergillus terreus under SSF of banana peels. Brsz. J. Microbiol. 45(4), 1485-1492 (2014). https://doi.org/10.1590/s1517-83822014000400045

3. Yao, W., Nokes, S.E.: First proof of concept of sustainable metabolite production from high solids fermentation of lignocellulosic biomass using a bacterial co-culture and cycling flush system. Bioresour. Technol. 173, 216-223 (2014). https://doi.org/10. 1016/j.biortech.2014.08.113

4. Zhao, B., Al Rasheed, H., Ali, I., Hu, S.: Efficient enzymatic saccharification of alkaline and ionic liquid-pretreated bamboo by highly active extremozymes produced by the co-culture of two halophilic fungi. Bioresour. Technol. 319, 124115 (2021). https://doi.org/10.1016/j.biortech.2020.124115

5. Relevance of microbial interactions to predictive microbiology: Malakar, P.K., Barker, G.C., Zwietering, M.H., Van't Riet, K. Int. J. Food Microbiol. 84, 263-272 (2003). https://doi.org/10.1016/ S0168-1605(02)00424-5

6. Wimpenny, J.W.T., Leistner, L., Thomas, L.V., Mitchell, A.J., Katsaras, K., Peetz, P.: Submerged bacterial colonies within food and model systems: their growth, distribution, and interactions. Int. J. Food Microbiol. 28, 299-315 (1995). https:// doi.org/10.1016/0168-1605(95)00065-8

7. Pin, C., Baranyi, J.: Predictive models as means to quantify the interactions of spoilage organisms. Int. J. Food Microbiol. 41, 59-72 (1998). https://doi.org/10.1016/S0168-1605(98) 00035-X

8. Goers, L., Freemont, P., Polizzi, K.M.: Co-culture systems and technologies: taking synthetic biology to the next level. J. R. Soc. Interface. (2014). https://doi.org/10.1098/rsif.2014.0065

9. Padmaperuma, G., Kapoore, R.V., Gilmour, D.J., Vaidyanathan, S.: Microbial consortia: a critical look at microalgae co-cultures for enhanced biomanufacturing. Crit. Rev. Biotechnol. 38, 690703 (2018). https://doi.org/10.1080/07388551.2017.1390728

10. Lio, J., Wang, T.: Solid-state fermentation of soybean and corn processing coproducts for potential feed improvement. J. Agric. Food Chem. 60, 7702-7709 (2012). https://doi.org/10.1021/jf301 $674 \mathrm{u}$

11. Oliva-Rodríguez, A. G., Quintero, J., Medina-Morales, M. A., Morales-Martínez, T. K., Rodríguez-De la Garza, J. A., MorenoDávila, M., Aroca, G., Rios González, L. J.: Clostridium strain selection for co-culture with Bacillus subtilis for butanol production from agave hydrolysates. Bioresour. Technol. 275, 410-415. (2019) https://doi.org/10.1016/j.biortech.2018.12.085

12. Molefe, N.M.: Co-production of Inulinase by Kluyveromyces marxianus and Saccharomyces cerevisiae in solid state. Vaal University of Technology, South Africa (2014)

13. Hynes, J., Müller, C.T., Jones, T.H., Boddy, L.: Changes in volatile production during the course of fungal mycelial interactions between Hypholoma fasciculare and Resinicium bicolor. J. Chem. Ecol. 33, 43-57 (2007). https://doi.org/10.1007/ s10886-006-9209-6

14. Patel, A.K., Singhania, R.R., Pandey, A.: Production, purification, and application of microbial enzymes. Biotechnol. Microbial Enzym. (2017). https://doi.org/10.1016/B978-0-12-8037256.00002-9

15. Castillo, M.R., Gutierrez-correa, M., Linden, J.C., Tengerdy, R.P.: Mixed culture solid substrate fermentation for cellulolytic enzyme production. Biotechnol. Lett. 16(9), 967-972 (1994). https://doi.org/10.1007/bf00128635

16. Fossi, B.T., Tavea, F., Fontem, L.A., Ndjouenkeu, R., Wanji, S.: Microbial interactions for enhancement of $\alpha$-amylase production by Bacillus amyloliquefaciens 04BBA 15 and Lactobacillus fermentum 04BBA19. Biotechnol. Rep. 4, 99-106 (2014). https:// doi.org/10.1016/j.btre.2014.09.004

17. Zafar, M., Arshad, F., Faizi, S., Anwar, Z., Imran, M., Mehmood, R.T.: HPLC based characterization of citric acid produced from indigenous fungal strain through single and co-culture fermentation. Biocatal. Agric. Biotechnol. 29, 101796 (2020). https://doi. org/10.1016/j.bcab.2020.101796

18. Ali, S.R., Anwar, Z., Irshad, M., Mukhtar, S., Warraich, N.T.: Bio-synthesis of citric acid from single and co-culture-based 
fermentation technology using agro-wastes. J. Radiat. Res. Appl. Sci. 9, 57-62 (2016). https://doi.org/10.1016/j.jrras.2015.09.003

19. Lynd, L.R., Weimer, P.J., Zyl, W.H.V., Isak, S., Lynd, L.R., Weimer, P.J., Zyl, W.H.V., Pretorius, I.S.: Microbial cellulose utilization: fundamentals and biotechnology. Microbiol. Mol. Biol. Rev. 66(3), 506-577 (2002). https://doi.org/10.1128/MMBR. 66.3.506

20. Li, S., Yang, X., Yang, S., Zhu, M., Wang, X.: Technology prospecting on enzymes: application, marketing and engineering. Comput. Struct. Biotechnol. J. 2(3), 1-11 (2012). https://doi. org/10.5936/csbj.201209017

21. Choi, J.M., Han, S.S., Kim, H.S.: Industrial applications of enzyme biocatalysis: current status and future aspects. Biotechnol. Adv. 33, 1443-1454 (2015). https://doi.org/10.1016/j.biote chadv.2015.02.014

22. Duza, M.B., Mastan, S.A.: Microbial enzymes and their applications-a review. Indo Am. J. Pharm. Res. 3, 651-657 (2013)

23. Pandey, A.: Solid-state fermentation. Biochem. Eng. J. 13, 81-84 (2003). https://doi.org/10.1016/s1369-703x(02)00121-3

24. Hansen, G.H., Lübeck, M., Frisvad, J.C., Lübeck, P.S., Andersen, B.: Production of cellulolytic enzymes from ascomycetes: Comparison of solid state and submerged fermentation. Process Biochem. 50, 1327-1341 (2015). https://doi.org/10.1016/j.procbio. 2015.05.017

25. Singhania, R.R., Patel, A.K., Soccol, C.R., Pandey, A.: Recent advances in solid-state fermentation. Biochem. Eng. J. 44, 13-18 (2009). https://doi.org/10.1016/j.bej.2008.10.019

26. Chen, H., He, Q.: Value-added bioconversion of biomass by solid-state fermentation. Chem Tech (2012). https://doi.org/10. 1002/jctb.3901

27. Nigam, P.S.N., Pandey, A.: Biotechnology for agro-industrial residues utilisation: utilisation of agro-residues. Braz Arch Biol Technol (2009). https://doi.org/10.1007/978-1-4020-9942-7

28. Ravichandran, S.: Vimala R (2012) Solid state and submerged fermentation for the production of bioactive substances: a comparative study. Int. J. Sci. Nat. 3, 480-486 (2012)

29. Dhillon, G.S., Oberoi, H.S., Kaur, S., Bansal, S., Brar, S.K.: Value-addition of agricultural wastes for augmented cellulase and xylanase production through solid-state tray fermentation employing mixed-culture of fungi. Ind. Crops Prod. 34, 1160 1167 (2011). https://doi.org/10.1016/j.indcrop.2011.04.001

30. Couto, S.R., Sanromán, M.Á.: Application of solid-state fermentation to food industry - a review. J. Food Eng. 76, 291-302 (2006). https://doi.org/10.1016/j.jfoodeng.2005.05.022

31. Thomas, L., Larroche, C., Pandey, A.: Current developments in solid-state fermentation. Eng J (2013). https://doi.org/10.1016/j. bej.2013.10.013

32. Suryanarayan, S.: Current industrial practice in solid state fermentations for secondary metabolite production: the Biocon India experience. Biochem. Eng. J. 13, 189-195 (2003). https:// doi.org/10.1016/S1369-703X(02)00131-6

33. Mitchell, D.A., Berovič, M., Krieger, N.: Introduction to solid-state fermentation bioreactors. Solid-State Ferment. Bioreact. Fundam. Des. Oper. (2006). https://doi.org/10. 1007/3-540-31286-2_3

34. Wang, L., Yang, S.T.: Solid state fermentation and its applications. Bioprocess Value-Added Products Renew Resour (2007). https://doi.org/10.1016/B978-044452114-9/50019-0

35. Hölker, U., Höfer, M., Lenz, J.: Biotechnological advantages of laboratory-scale solid-state fermentation with fungi. Appl. Microbiol. Biotechnol. 64, 175-186 (2004). https://doi.org/10. 1007/s00253-003-1504-3

36. Raimbault, M.: General and microbiological aspects of solid substrate fermentation. Electron. J. Biotechnol. 1, 114-140 (1998). https://doi.org/10.2225/vol1-issue3-fulltext-9
37. Robinson, T., Singh, D., Nigam, P.: Solid-state fermentation: A promising microbial technology for secondary metabolite production. Appl. Microbiol. Biotechnol. 55, 284-289 (2001). https://doi.org/10.1007/s002530000565

38. Durand, A., Chereau, D.: A new pilot reactor for solid-state fermentation: application to the protein enrichment of sugar beet pulp. Biotechnol. Bioeng. 31, 476-486 (1988). https://doi.org/ 10.1002/bit.260310513

39. Durand, A.: Bioreactor designs for solid state fermentation. Biochem. Eng. J. 13, 113-125 (2003). https://doi.org/10.1016/ S1369-703X(02)00124-9

40. Watson, D.C.: Current development in the potable distilling industry. Crit. Rev. Biotechnol. 2(2), 147-192 (1984). https:// doi.org/10.3109/07388558409082584

41. Pelczar, M.J., Chan, E.C.S., Krieg, N.R.: Microbiology, 5th edn., pp. 707-711. McGraw-Hill, New York (1993)

42. Tshikantwa, T.S., Ullah, M.W., He, F., Yang, G.: Current trends and potential applications of microbial interactions for human welfare. Front. Microbiol. (2018). https://doi.org/10.3389/fmicb. 2018.01156

43. Ghosh, A.R.: Appraisal of microbial evolution to commensalism and pathogenicity in humans. Clin. Med. Insights Gastroenterol. 6, 1-12 (2013). https://doi.org/10.4137/CGast.S11858

44. Schink, B.: Synergistic interactions in the microbial world. Antonie Van Leeuwenhoek 81, 257-261 (2002). https://doi.org/ 10.1023/A:1020579004534

45. Kunamneni, A., Permaul, K., Singh, S.: Amylase production in solid state fermentation by the thermophilic fungus Thermomyces lanuginosus. J. Biosci. Bioeng. 100, 168-171 (2005). https:// doi.org/10.1263/jbb.100.168

46. Auria, R., Palacios, J., Revah, S.: Determination of the interparticular effective diffusion coefficient for $\mathrm{CO}_{2}$ and $\mathrm{O}_{2}$ in solid state fermentation. Biotechnol. Bioeng. 39, 898-902 (1992). https:// doi.org/10.1002/bit.260390903

47. Renge, V.C., Khedkar, S.V., Nandurkar, N.R.: Enzyme synthesis by fermentation method: a review. Sci. Rev. Chem. Commun. 2, 585-590 (2012)

48. Krishna, C.: Solid-state fermentation systems-an overview. Crit. Rev. Biotechnol. 25, 1-30 (2005). https://doi.org/10.1080/07388 550590925383

49. Nandakumar, M.P., Thakur, M.S., Raghavarao, K.S.M.S., Ghildyal, N.P.: Mechanism of solid particle degradation by Aspergillus niger in solid state fermentation. Process Biochem. 29, 545-551 (1994). https://doi.org/10.1016/0032-9592(94) 80016-2

50. Sathya, R., Pradeep, B.V., Angayarkanni, J., Palaniswamy, M.: Production of milk clotting protease by a local isolate of Mucor circinelloides under SSF using agro-industrial wastes. Biotechnol. Bioprocess. Eng. 14, 788-794 (2009). https://doi.org/10. 1007/s 12257-008-0304-0

51. Pandey, A., Soccol, C.R., Nigam, P., Brand, D., Mohan, R., Roussos, S.: Biotechnological potential of coffee pulp and coffee husk for bioprocesses. Biochem. Eng. J. 6, 153-162 (2000). https:// doi.org/10.1016/S1369-703X(00)00084-X

52. Edwinoliver, N.G., Thirunavukarasu, K., Naidu, R.B., Gowthaman, M.K., Kambe, T.N., Kamini, N.R.: Scale up of a novel tri-substrate fermentation for enhanced production of Aspergillus niger lipase for tallow hydrolysis. Bioresour. Technol. 101, 6791-6796 (2010). https://doi.org/10.1016/j.biortech.2010.03. 091

53. De Almeida, A.F., Dias, K.B., Da Silva, A.C.C., Terrasan, C.R.F., Tauk-Tornisielo, S.M., Carmona, E.C.: Agroindustrial wastes as alternative for lipase production by Candida viswanathii under solid-state cultivation: purification, biochemical properties, and its potential for poultry fat hydrolysis. Enzyme Res. (2016). https://doi.org/10.1155/2016/1353497 
54. Mostafa, F.A., Aty, A.A.E., Wehaidy, H.R.: Original research article improved xylanase production by mixing low cost wastes and novel co-culture of three marine-derived fungi in solid state fermentation. Int. J. Curr. Microbiol. Appl. Sci. 3, 336-349 (2014)

55. Olorunnisola, K.S., Jamal, P., Alam, Z.: Growth, substrate consumption, and product formation kinetics of Phanerochaete chrysosporium and Schizophyllum commune mixed culture under solid-state fermentation of fruit peels. 3 Biotech. 8(10), 429 (2018). https://doi.org/10.1007/s13205-018-1452-3

56. Amaro-Reyes, A., Gracida, J., Huizache-Peña, N., ElizondoGarcía, N., Salazar-Martínez, J., García Almendárez, B.E., Regalado, C.: On-site hydrolytic enzymes production from fungal co-cultivation of Bermuda grass and corn cob. Bioresour. Technol. 212, 334-337 (2016). https://doi.org/10.1016/j.biortech. 2016.04.070

57. Vibha, K., Negi, S.: Enhanced production of laccase and pectinase using co-culture of Trametes hirsuta and Phanerochaete sp through EVOP-factorial design technique. 3 Biotech. 8(12), 490 (2018). https://doi.org/10.1007/s13205-018-1516-4

58. Cotârleț, M., Stănciuc, N., Bahrim, G.E.: Yarrowia lipolytica and Lactobacillus paracase $i$ solid state fermentation as a valuable biotechnological tool for the pork lard and okara's biotransformation. Microorganisms. 8, 1-12 (2020). https://doi. org/10.3390/microorganisms 8081098

59. Lodha, A., Pawar, S., Rathod, V.: Optimised cellulase production from fungal co-culture of Trichoderma reesei NCIM 1186 and Penicillium citrinum NCIM 768 under solid state fermentation. J. Environ. Chem. Eng. 8, 103958 (2020). https://doi.org/ 10.1016/j.jece.2020.103958

60. Norsalwani, T.L.T., Norulaini, N.A.R.N., Massaud, B.N.M.: Cellulase activity and glucose production by Bacillus cereus monoculture and co-culture utilizing palm kernel cake (PKC) under solid state fermentation. IPCBEE 33, 172-177 (2012)

61. Olofsson, K., Bertilsson, M., Lidén, G.: A short review on $\mathrm{SSF}$ - an interesting process option for ethanol production from lignocellulosic feedstocks. Biotechnol. Biofuels. 1, 1-14 (2008). https://doi.org/10.1186/1754-6834-1-7

62. Mosier, N., Wyman, C., Dale, B., Elander, R., Lee, Y.Y., Holtzapple, M., Ladisch, M.: Features of promising technologies for pretreatment of lignocellulosic biomass. Bioresour. Technol. 96, 673-686 (2005). https://doi.org/10.1016/j.biortech. 2004.06.025

63. Yao, W., Nokes, S.E.: Phanerochaete chrysosporium pretreatment of biomass to enhance solvent production in subsequent bacterial solid-substrate cultivation. Biomass Bioenergy. 62, 100-107 (2014). https://doi.org/10.1016/j.biombioe.2014.01.009

64. Sun, Y., Cheng, J.: Hydrolysis of lignocellulosic materials for ethanol production: a review. Bioresour. Technol. 83, 1-11 (2002). https://doi.org/10.1016/S0960-8524(01)00212-7

65. Zhang, Y., Ghaly, A.E., Li, B.: Physical properties of rice residues as affected by variety and climatic and cultivation conditions in three continents. Am. J. Appl. Sci. 9, 1757-1768 (2013). https://doi.org/10.3844/ajassp.2012.1757.1768

66. Chuetor, S., Barakat, A., Ruiz, T., Rouau, X.: Chemo-mechanical pretreatments of rice straw for biofuels and bioproducts: physical and biochemical characterization. Conference 1-2 (2015).

67. Bak, J.S.: Process evaluation of electron beam irradiation-based biodegradation relevant to lignocellulose bioconversion. Springerplus 3, 487 (2014). https://doi.org/10.1186/2193-1801-3-487

68. Dimos, K., Paschos, T., Louloudi, A., Kalogiannis, K.G., Lappas, A.A., Papayannakos, N., Kekos, D., Mamma, D.: Effect of various pretreatment methods on bioethanol production from cotton stalks. Fermentation 5, 1-12 (2019). https://doi.org/10.3390/ fermentation 5010005
69. Yu, H., Guo, G., Zhang, X., Yan, K., Xu, C.: The effect of biological pretreatment with the selective white-rot fungus Echinodontium taxodii on enzymatic hydrolysis of softwoods and hardwoods. Bioresour. Technol. 100, 5170-5175 (2009). https:// doi.org/10.1016/j.biortech.2009.05.049

70. Lynd, L.R., Elander, R.T., Wyman, C.E.: Likely features and costs of mature biomass ethanol technology. Appl. Biochem. Biotechnol. 57(58), 741-761 (1996)

71. Vandamme, E.J., Derycke, D.G.: Microbial inulinases: Fermentation process, properties, and applications. Adv. Appl. Microbiol. 29:139-176 (1983). https://doi.org/10.1016/S0065-2164(08) 70356-3

72. Trzcinski antoine: solid state fermentation of soybean residue (2018) https://doi.org/10.13140/RG.2.2.25843.22569

73. Domínguez, A., Rivela, I., Couto, S.R., Sanromán, M.Á.: Design of a new rotating drum bioreactor for ligninolytic enzyme production by Phanerochaete chrysosporium grown on an inert support. Process Biochem. 37, 549-554 (2001). https://doi.org/10.1016/S0032-9592(01)00233-3

74. Roussos, S., Raimbault, M., Prebois, J.P., Lonsane, B.K.: Zymotis, a large scale solid -state fermenter design and evaluation. Appl. Biochem. Biotechnol. 42, 37-52 (1993). https:// doi.org/10.1007/BF02788900

75. Webb, C.: Design aspects of solid-state fermentation as applied to microbial bioprocessing. J. Appl. Biotechnol. Bioeng. (2017). https://doi.org/10.15406/jabb.2017.04.00094

76. Planinic, M., Zelic, B., Cubel, I., Bucic-Kojic, A., Tišma, M.: Corn forage biological pretreatment by Trametes versicolor in a tray bioreactor. Waste Manag. Res. 34, 802-809 (2016). https://doi.org/10.1177/0734242X16654979

77. Swain, M.R., Mishra, J., Thatoi, H.: Bioethanol production from sweet potato (Ipomoea batatas L.) flour using co-culture of Trichoderma sp. and Saccharomyces cerevisiae in solid-state fermentation. Braz. Arch. Biol. Technol. 56:171-179 (2013). https://doi.org/10.1590/S1516-89132013000200002

78. Pinheiro, V.E., Michelin, M., Vici, A.C., de Almeida, P.Z., de Moraes Polizeli, M. de L.T.: Trametes versicolor laccase production using agricultural wastes: a comparative study in Erlenmeyer flasks, bioreactor and tray. Bioprocess Biosyst. Eng. 43: 507-514 (2020). https://doi.org/10.1007/ s00449-019-02245-Z

79. Singh, V., Haque, S., Niwas, R., Srivastava, A., Pasupuleti, M., Tripathi, C.K.M.: Strategies for fermentation medium optimization: an in-depth review. Front. Microbiol. 7, 2087 (2017). https://doi.org/10.3389/fmicb.2016.02087

80. Panda, B.P., Ali, M., Javed, S.: Fermentation process optimization. Res. J. Microbiol. 2(3), 201-208 (2007)

81. Saxena, R.K., Sheoran, A., Giri, B., Davidson, W.S.: Purification strategies for microbial lipases. J. Microbiol. Methods. 52, 1-18 (2003). https://doi.org/10.1016/s0167-7012(02)00161-6

82. Singh, R., Singh, T.: Inulinase and pullulanase production from agro-industrial residues. Ind. Biotechnol. (2019). https://doi.org/ 10.1515/9783110563337-001

83. Golunski, S., Silva, M.F., Marques, C.T., Rosseto, V., Kaizer, R.R., Mossi, A.J., Rigo, D., Dallago, R.M., Di Luccio, M., Treichel, H.: Purification of inulinases by changing the ionic strength of the medium and precipitation with alcohols. Acad. Bras. Cienc. 89, 57-63 (2017). https://doi.org/10.1590/00013765201720160367

84. Ewelina, Ł, Kowalczyk, T., Olejniczak, S., Sakowicz, T.: Extraction and purification methods in downstream processing of plantbased recombinant proteins. Protein Expr. Purif. 120, 110-117 (2016). https://doi.org/10.1016/j.pep.2015.12.018

85. Sujani, S., Seresinhe, R.T.: Exogenous enzymes in ruminant nutrition: a review. Asian J. Anim. Sci. 9, 85-99 (2015). https:// doi.org/10.3923/ajas.2015.85.99 
86. Shrestha, P., Khanal, S.K., Pomettoiii, A.L., Van Leeuwen, J.: Enzyme production by wood-rot and soft-rot fungi cultivated on corn fiber followed by simultaneous saccharification and fermentation. J. Agric. Food Chem. 57, 4156-4161 (2009). https://doi. org/10.1021/jf900345n

87. Paranthaman, R., Vidyalakshmi, R.: Effects of fungal co-culture for the biosynthesis of tannase and gallic acid from grape wastes under solid state fermentation. Glob. J. Biotechnol. 4, 29-36 (2009)

88. Marga, F., Ghakis, C., Dupont, C., Morosoli, R., Kluepfel, D.: Improved production of mannanase by Streptomyces lividans. Appl. Environ. Microbiol. 62, 4656-4658 (1996). https://doi.org/ 10.1128/aem.62.12.4656-4658.1996

89. Rosero-Chasoy, G., Rodríguez-Jasso, R.M., Aguilar, C.N., Buitrón, G., Chairez, I., Ruiz, H.A.: Microbial co-culturing strategies for the production high-value compounds, a reliable framework towards sustainable biorefinery implementation-an overview. Bioresour. Technol. (2021). https://doi.org/10.1016/j.biortech. 2020.124458

90. Cheng, Y., Hu, S., Li, T., Qiu, Z., Zhu, Y.: Production of diosgenin from Dioscorea zingiberensis with mixed culture in a new tray bioreactor. Biotechnol. Biotechnol. Equip. 30, 158-164 (2016). https://doi.org/10.1080/13102818.2015.1082897

91. Shukla, L., Suman, A., Verma, P., Yadav, A.N., Saxena, A.K.: Syntrophic microbial system for ex-situ degradation of paddy straw at low temperature under controlled and natural environment. J. Appl. Biol. Biotechnol. 4(02), 30-37 (2016). https://doi. org/10.7324/jabb.2016.40205

92. Oberoi, H.S., Babbar, N., Dhaliwal, S.S., Kaur, S., Vadlani, P.V., Bhargav, V.K., Patil, R.T.: Enhanced oil recovery by pre-treatment of mustard seeds using crude enzyme extract obtained from mixed-culture solid-state fermentation of Kinnow (Citrus reticulata) waste and wheat bran. Food Bioproc. Technol. 5, 759-767 (2012). https://doi.org/10.1007/s11947-010-0380-y

93. Olaniyi, O.O., Akinyele, B.J.: Production of $\beta$-mannanase by Penicillium italicum subjected to different growth conditions. Biotechnol. J. Int. 22, 1-8 (2018). https://doi.org/10.9734/bji/2018/6763

94. Bankole, P.O., Adekunle, A.A., Govindwar, S.P.: Biodegradation of a monochlorotriazine dye, cibacron brilliant red 3B-A in solid state fermentation by wood-rot fungal consortium, Daldinia concentrica and Xylaria polymorpha: Co-biomass decolorization of cibacron brilliant red 3B-A dye. Int. J. Biol. Macromol. 120, 19-27 (2018). https://doi.org/10.1016/j.ijbiomac.2018.08.068

95. Ramakrishnan, P., Rajagopal, V., Kunjithapatham, S.: Effects of fungal co-culture for the biosynthesis of tannase and gallic acid from grape wastes under solid state fermentation. Glob. J. Biotech. Biochem. 4(1), 29-36 (2009)

96. Pant, G., Prakash, A., Pavani, J.V.P., Bera, S., Deviram, G.V.N.S., Kumar, A., Panchpuri, M., Prasuna, R.G.: Production, optimization and partial purification of protease from Bacillus subtilis. J. Taibah Univ. Sci. 9, 50-55 (2015). https://doi.org/10.1016/j. jtusci.2014.04.010

97. Ahmed, I., Zia, M.A., Hussain, M.A., Akram, Z., Naveed, M.T., Nowrouzi, A.: Bioprocessing of citrus waste peel for induced pectinase production by Aspergillus niger; its purification and characterization. J. Radiat. Res. Appl. Sci. 9, 148-154 (2016). https://doi.org/10.1016/j.jrras.2015.11.003

98. Vera, C., Córdova, A., Aburto, C., Guerrero, C., Suárez, S., Illanes, A.: Synthesis and purification of galacto-oligosaccharides: state of the art. World J. Microbiol. Biotechnol. (2016). https://doi.org/10.1007/s11274-016-2159-4

99. Cayetano-Cruz, M., Pérez de los Santos, A.I., García-Huante, Y., Santiago-Hernández, A., Pavón-Orozco, P., López y López, V.E., Hidalgo-Lara, M.E.: High level expression of a recombinant xylanase by Pichia pastoris cultured in a bioreactor with methanol as the sole carbon source: Purification and biochemical characterization of the enzyme. Biochem. Eng. J. 112, 161-169 (2016). https://doi.org/10.1016/j.bej.2016.04.014

100. Majolagbe, O., Oloke, J., Deka-Boruah, H., Adetunji, C., Bordoloi, A., Borah, M.: Extraction and purification of extracellular laccase from wild, mutants and hybrid strains of two white-rot fungus and its applications in decolorization and ligninolysis. J. Microbiol. Biotechnol. Food Sci. 2020, 998-1016 (2020)

101. Singh, R.S., Chauhan, K., Kennedy, J.F.: A panorama of bacterial inulinases: production, purification, characterization and industrial applications. Int. J. Biol. Macromol. 96, 312-322 (2017). https://doi.org/10.1016/j.ijbiomac.2016.12.004

102. Padmavathi, T., Bhargavi, R., Priyanka, P.R., Niranjan, N.R., Pavitra, P.V.: Screening of potential probiotic lactic acid bacteria and production of amylase and its partial purification. J. Genet. Eng. Biotechnol. 16, 357-362 (2018). https://doi.org/10.1016/j.jgeb.2018.03.005

103. Islam, F., Roy, N.: Screening, purification and characterization of cellulase from cellulase producing bacteria in molasses. BMC Res. Notes. 11, 1-6 (2018). https://doi.org/10.1186/ s13104-018-3558-4

104. Soni, H., Rawat, H.K., Pletschke, B.I., Kango, N.: Purification and characterization of $\beta$-mannanase from Aspergillus terreus and its applicability in depolymerization of mannans and saccharification of lignocellulosic biomass. 3 Biotech. 6(2), 136 (2016). https://doi.org/10.1007/s13205-016-0454-2

105. Narasimha, G., Sridevi, A., Ramanjaneyulu, G., Rajasekhar Reddy, B.: Purification and characterization of $\beta$-glucosidase from Aspergillus niger. Int. J. Food Prop. 19, 652-661 (2016). https://doi.org/10.1080/10942912.2015.1023398

106. Singh, G.G.A., Singh, A.K.R., Mahajan, J.K.R.: Microbial pectinases: an ecofriendly tool of nature for industries. 3 Biotech. 6 , 47 (2016). https://doi.org/10.1007/s13205-016-0371-4

107. Bhat, M.K.: Cellulases and related enzymes in biotechnology. Biotechnol. Adv. 18, 355-383 (2000). https://doi.org/10.1016/ S0734-9750(00)00041-0

108. Jayani, R.S., Saxena, S., Gupta, R.: Microbial pectinolytic enzymes: a review. Process. Biochem. 40, 2931-2944 (2005). https://doi.org/10.1016/j.procbio.2005.03.026

109. Mabrouk, M.E.M., Ahwany, A.M.D.E.: Production of $\beta$-mannanase by Bacillus amylolequifaciens $10 \mathrm{~A} 1$ cultured on potato peels. Afr. J. Biotechnol. 7, 1123-1128 (2008). https://doi.org/ 10.5897/AJB08.047

110. Maurya, D.P., Singla, A., Negi, S.: An overview of key pretreatment processes for biological conversion of lignocellulosic biomass to bioethanol. 3 Biotech 5, 597-609 (2015). https://doi.org/ 10.1007/s13205-015-0279-4

111. Meenakshi, S.G., Bhalla, A., Hoondal, G.S.: Solid state fermentation and characterization of partially purified thermostable mannanase from Bacillus sp. MG-33. BioResources 5(3), 1689-1701 (2010)

112. Ladisch, M.R.: Fermentation-derived butanol and scenarios for its uses in energy-related applications. Enzyme Microb. Technol. 13, 280-283 (1991). https://doi.org/10.1016/0141-0229(91) 90143-X

113. Nigam, P.S., Singh, A.: Production of liquid biofuels from renewable resources. Prog. Energy Combust. Sci. 37, 52-68 (2011). https://doi.org/10.1016/j.pecs.2010.01.003

114. Qureshi, N., Blaschek, H.P.: ABE production from corn: A recent economic evaluation. J. Ind. Microbiol. Biotechnol. 27, 292-297 (2001). https://doi.org/10.1038/sj.jim.7000123

115. Minussi, R.C., Miranda, M.A., Silva, J.A., Ferreira, C.V., Aoyama, H., Marangoni, S., Rotilio, D., Pastore, G.M., Durán, N.: Purification, characterization and application of laccase from Trametes versicolor for colour and phenolic removal of olive mill wastewater in the presence of 1-hydroxybenzotriazole. Afr. J. Biotechnol. 6, 1248-1254 (2007). https://doi.org/10.4314/ajb.v6i10.57427

116. Selinheimo, E., Saloheimo, M., Ahola, E., Westerholm-Parvinen, A., Kalkkinen, N., Buchert, J., Kruus, K.: Production and characterization 
of a secreted, C-terminally processed tyrosinase from the filamentous fungus Trichoderma reesei. FEBS J. 273, 4322-4335 (2006). https:// doi.org/10.1111/j.1742-4658.2006.05429.x
Publisher's Note Springer Nature remains neutral with regard to jurisdictional claims in published maps and institutional affiliations. 